\title{
Adenylate Cyclase in Mycobacterium smegmatis
}

\author{
By C. H. LEE* \\ Department of Clinical Biochemistry, University of Otago, \\ Medical School, Dunedin, New Zealand
}

(Received 8 May 1978; revised 2 June 1978)

\section{INTRODUCTION}

The intracellular concentration of cyclic AMP depends on the relative activities of adenylate cyclase and phosphodiesterase. Adenylate cyclase [ATP pyrophosphate-lyase (cyclizing); EC 4.6.1.1] catalyses the formation of cyclic AMP and pyrophosphate from ATP. Cyclic AMP and phosphodiesterase have been identified in Mycobacterium smegmatis (Lee, 1977, 1978) and the present paper describes some properties of the adenylate cyclase in this bacterium.

\section{METHODS}

Culture and harvest of micro-organisms. Mycobacterium smegmatis (NCTC 523) was cultured as previously described (Lee, 1977, 1978). Harvested bacteria were stored at $-80^{\circ} \mathrm{C}$.

Preparation of extracts. Frozen bacteria $(2 \cdot 1 \mathrm{~g}$ wet $\mathrm{wt}$ ) were thawed, suspended in $4 \mathrm{mi} 0 \cdot 25 \mathrm{M}-\mathrm{Tris} / \mathrm{HCl}$ buffer ( $\mathrm{pH} \mathrm{7.3)} \mathrm{and} \mathrm{ultrasonically} \mathrm{disintegrated} \mathrm{at} 0{ }^{\circ} \mathrm{C}$ at $10 \mathrm{kHz}$ for $80 \mathrm{~s}$ with a $100 \mathrm{~W}$ instrument. The homogenate was centrifuged at $4000 \mathrm{~g}$ for $10 \mathrm{~min}$ at $4{ }^{\circ} \mathrm{C}$ to remove unbroken cells. The supernatant fraction was then centrifuged at $43500 \mathrm{~g}$ for $20 \mathrm{~min}$ at $4^{\circ} \mathrm{C}$. The supernatant was discarded and the pellet was suspended in $4 \mathrm{ml} \mathrm{0.25} \mathrm{M}$-Tris/ $\mathrm{HCl}$ buffer $(\mathrm{pH} 7.3)$ with a glass homogenizer. This suspension contained all the adenylate cyclase activity and was stable for at least $4 \mathrm{~d}$ at $-80^{\circ} \mathrm{C}$. Protein was determined by the method of Lowry et al. (1951) using bovine serum albumin as standard. Determination of $K_{\mathrm{m}}$ for adenylate cyclase was done with extracts prepared in $0.25 \mathrm{M}-\mathrm{Tris} / \mathrm{HCl}$ buffer $(\mathrm{pH} \mathrm{9.0})$.

Assay of adenylate cyclase. The assay mixture (total volume $150 \mu \mathrm{l}$ ) contained: $12 \cdot 5 \mu \mathrm{mol} \mathrm{Tris} / \mathrm{HCl}$ buffer (pH 9.0), $2.7 \mu \mathrm{mol} \mathrm{MgSO}_{4}$, ATP (various concentrations) and extract ( $0.4 \mathrm{mg}$ protein). The mixture was incubated for an appropriate time ( 3 to $5 \mathrm{~min}$ ) at $37^{\circ} \mathrm{C}$ and the reaction was stopped by adding $100 \mu 1$ of cold $0.25 \mathrm{M}-\mathrm{ZnSO}_{4}$ followed by $100 \mu \mathrm{l}$ of cold $0.25 \mathrm{M}-\mathrm{Ba}(\mathrm{OH})_{2}$. The tubes were mixed and centrifuged at $10000 \mathrm{~g}$ for $20 \mathrm{~min}$ at $4{ }^{\circ} \mathrm{C}$. A sample of the supernatant $(150 \mu \mathrm{I})$ was applied to a column $(2.5 \times 0.5 \mathrm{~cm})$ of anion exchange resin (Bio-Rad, AG1-X2, 200 to 400 mesh). The column was washed with $5 \mathrm{ml}$ water and cyclic AMP was eluted with $2 \mathrm{ml} \mathrm{HCl}(\mathrm{pH} \mathrm{1.5})$. A sample of the effluent was neutralized with $0.5 \mathrm{M}-\mathrm{NaOH}$ and assayed for cyclic AMP. In some experiments, including those on the effects of metal ions on adenylate cyclase activity, cyclic AMP was assayed directly in the supernatant after precipitation with $\mathrm{ZnSO}_{4}$ and $\mathrm{Ba}(\mathrm{OH})_{2}$. Both methods gave the same results. In all experiments less than $9 \%$ of the substrate was utilized and formation of cyclic AMP was linear with time and enzyme concentration. The identity of cyclic AMP was confirmed by digestion with phosphodiesterase and adsorption with charcoal.

The modified version of the assay was also used in studies on the effect of metabolites (and other compounds) on adenylate cyclase activity. In these experiments, the mixture (total volume $200 \mu \mathrm{l}$ ) contained: $12.5 \mu \mathrm{mol}$ Tris $/ \mathrm{HCl}$ buffer ( $\mathrm{pH} \mathrm{7.3)}, 0.3 \mu \mathrm{mol}$ ATP, $4.0 \mu \mathrm{mol} \mathrm{MnCl}_{2}, 0.2 \mu \mathrm{mol}$ metabolite (or other compound) and extract $\left(0.53 \mathrm{mg}\right.$ protein). The reaction mixture was incubated at $37^{\circ} \mathrm{C}$ for $4 \mathrm{~min}$ and the reaction was stopped by adding $1 \mathrm{ml}$ of cold $0.25 \mathrm{M}-\mathrm{ZnSO}_{4}$ followed by $1 \mathrm{ml}$ of cold $0 \cdot 25 \mathrm{M}-\mathrm{Ba}(\mathrm{OH})_{2}$. After centrifuging at $10000 \mathrm{~g}$ for $20 \mathrm{~min}$ at $4^{\circ} \mathrm{C}, 10 \mu 1$ of the supernatant were assayed for cyclic AMP. Enzyme activity in the absence of added compounds was $3.02 \mathrm{nmol}$ cyclic AMP formed $\mathrm{min}^{-1}$ (mg protein) ${ }^{-1}$. Results are the average of triplicate determinations. All compounds were prepared just before use by dissolving in $0.06 \mathrm{M}$-Tris $/ \mathrm{HCl}$ buffer $(\mathrm{pH} \mathrm{7.3)}$. Suitable controls showed that the reaction mixture was maintained at $\mathrm{pH} 7 \cdot 3$ and the added compounds did not affect the assay for cyclic AMP.

Measurement of cyclic AMP. Cyclic AMP was assayed by the competitive protein binding procedure (Gilman, 1970).

* Present address: Department of Biochemistry and Microbiology, University of Agriculture, Serdang, Selangor, Malaysia. 


\section{Table 1. Effect of cations at their optimum concentrations on adenylate cyclase activity}

Activity was assayed at $\mathrm{pH} 7.3$ by the modified procedure described in Methods. Adenylate cyclase activity in the absence of added cation (taken as $100 \%$ ) was $2.8 \mathrm{nmol}$ cyclic AMP formed $\min ^{-1}$ (mg protein) ${ }^{-1}$. The various cations (used as chlorides) did not affect the assay for cyclic AMP.

$\begin{array}{lcc}\text { Cation } & \begin{array}{c}\text { Optimum concn } \\ (\mathrm{mM})\end{array} & \begin{array}{c}\text { Activity } \\ \text { (\% of control) }\end{array} \\ \mathrm{Mn}^{2+} & 8 \cdot 5 & 6113 \\ \mathrm{Co}^{2+} & 6 \cdot 67 & 4267 \\ \mathrm{Fe}^{2+} & 6 \cdot 67 & 2591 \\ \mathrm{Ca}^{2+} & 6 \cdot 67 & 560 \\ \mathrm{Cd}^{2+} & 1 \cdot 33 & 404 \\ \mathrm{Zn}^{2+} & 1 \cdot 33 & 383 \\ \mathrm{Ni}^{2+} & 6 \cdot 67 & 358 \\ \mathrm{Ba}^{2+} & 13 \cdot 3 & 283 \\ \mathrm{Mg}^{2+} & 3 \cdot 0 & 275 \\ \mathrm{Cu}^{2+} & 0 \cdot 13 & 258 \\ \mathrm{Fe}^{3+} & 1 \cdot 33 & 136 \\ \mathrm{Na}^{+} & 13 \cdot 3 & 129 \\ \mathrm{Li}^{+} & 0 \cdot 33 & 106\end{array}$

Liquid scintillation counting. Radioactivity was determined as described by Lee (1978).

Materials. All the organic compounds tested for their effects on adenylate cyclase activity were obtained from Sigma.

\section{RESULTS}

Stability of enzyme. The adenylate cyclase of $M$. smegmatis was reasonably stable and could be left at $3{ }^{\circ} \mathrm{C}$ for $5 \mathrm{~h}$ or stored at $-80^{\circ} \mathrm{C}$ for at least $4 \mathrm{~d}$ without any loss of enzyme activity.

Determination of $K_{\mathrm{m}}$. The $K_{\mathrm{m}}$ value for ATP at $\mathrm{pH} 7 \cdot 3$ and 9.0 was from 1.0 to $1.3 \mathrm{mM}$. Effect of $\mathrm{pH}$. Maximum enzyme activity occurred at $\mathrm{pH} 7 \cdot 5$, with only $45 \%$ of the maximum activity at $\mathrm{pH} 9 \cdot 0$.

Effect of cations. At $3.0 \mathrm{~mm}-\mathrm{Mg}^{2+}$, adenylate cyclase activity was stimulated by $175 \%$ and increasing the $\mathrm{Mg}^{2+}$ concentration up to $13.3 \mathrm{mM}$ did not decrease enzyme activity. Amongst the metal ions tested (Table 1), $\mathrm{Mn}^{2+}, \mathrm{Co}^{2+}$ and $\mathrm{Fe}^{2+}$ were the most stimulatory. Enzyme activity was maximum with $8.5 \mathrm{mM}-\mathrm{Mn}^{2+}$ and remained unchanged up to $26.6 \mathrm{~mm}$. $\mathrm{Mn}^{2+}$ was about 20 times as effective as $\mathrm{Mg}^{2+}$ if both were tested at their optimum concentrations. At relatively low concentrations $(0.6 \mathrm{mM}), \mathrm{Cu}^{2+}$ was inhibitory, while $\mathrm{Zn}^{2+}$ was inhibitory only at $9.0 \mathrm{~mm}$. In the presence of $\mathrm{Fe}^{3+}(1.33 \mathrm{~mm})$ a slight stimulation of enzyme activity was observed but the enzyme was inhibited at concentrations greater than $2.3 \mathrm{~mm}$. $\mathrm{Al}^{3+}$ at all concentrations inhibited enzyme activity. EDTA ( $\left.6.3 \mathrm{~mm}\right)$ abolished enzyme activity in the absence of added cations. No marked effect on the adenylate cyclase was observed with any monovalent cation tested; $\mathrm{NH}_{4}{ }^{+}, \mathrm{Cs}^{+}$and $\mathrm{K}^{+}$had no effect on the enzyme.

Effect of fuoride and hormones. Fluoride (1 to $5 \mathrm{~mm}$ ) inhibited enzyme activity by $72 \%$ but adrenaline $\left(0.3\right.$ to $\left.0.85 \mu \mathrm{g} \mathrm{ml}^{-1}\right)$ and glucagon $\left(0.3\right.$ to $\left.0.75 \mu \mathrm{g} \mathrm{ml}^{-1}\right)$ had no effect on the activity.

Effect of metabolic intermediates and related compounds. All compounds were tested at $1 \mathrm{mM}$, and percentage inhibitions are shown in parentheses. The following compounds inhibited the adenylate cyclase of $M$. smegmatis: phosphoenolpyruvate $(74 \%)$, citrate $(71 \%)$, L-malate $(70 \%)$, oxaloacetate $(32 \%)$, succinate $(31 \%)$, L-lactate $(20 \%)$, glucose 6-phosphate $(18 \%), 2$-oxoglutarate $(16 \%)$ and pyruvate $(14 \%)$. This inhibition was not caused by depletion of $\mathrm{Mn}^{2+}$ which was present in excess in the reaction mixture. 
In view of the importance of glycerol metabolism in this bacterium (Clark, 1971), the following compounds were tested and all were shown to inhibit activity: NADP $+(76 \%)$, $\mathrm{NAD}^{+}(65 \%)$, NADH $(26 \%)$, dihydroxyacetone $(19 \%)$, $\alpha$-glycerophosphate $(17 \%)$, glycerol $(8 \%)$ and NADPH $(7 \%)$.

Thiamin pyrophosphate $(90 \%)$, aneurine $(64 \%)$ and pyridoxine $(56 \%)$ inhibited adenylate cyclase activity. Lysine plus pyridoxine inhibited enzyme activity by $81 \%$ whereas lysine relieved inhibition in Escherichia coli (Tao \& Huberman, 1970).

Since extracts of $M$. smegmatis contain carboxylating enzymes (Clark, 1971), the effects of $\mathrm{Na}_{2} \mathrm{CO}_{3}$ and $\mathrm{NaHCO}_{3}$ on enzyme activity were tested; they stimulated activity by 30 and $41 \%$, respectively.

Asparagine and ammonium molybdate, which are constituents of the growth medium, inhibited cyclic AMP synthesis by 35 and $85 \%$, respectively. Coenzyme A ( $85 \%$ ), ribose 5 -phosphate $(18 \%)$, pyrophosphate $(17 \%)$ and glucose 1 -phosphate $(5 \%)$ all inhibited adenylate cyclase activity.

\section{DISCUSSION}

Adenylate cyclase of $M$. smegmatis was associated only with the particulate fraction and activity was detected in the absence of added pyruvate. Membrane-bound adenylate cyclases have also been reported in Neurospora crassa (Flawia \& Torres, 1972), Tetrahymena pyriformis (Kassis \& Kindler, 1975), Saccharomyces cerevisiae (Wheeler et al., 1974), Escherichia coli (Ide, 1969; Tao \& Huberman, 1970) and other organisms (Ide, 1971). This localization contrasts with that in Brevibacterium liquefaciens (Hirata \& Hayaishi, 1967), Streptococcus salivarius (Khandelwal \& Hamilton, 1971) and Bordetella pertussis (Hewlett $\&$ Wolff, 1976) where the adenylate cyclase is soluble. The enzyme in $M$. smegmatis has a similar $K_{\mathrm{m}}$ to the enzymes of $E$. coli (Ide, 1969), B. liquefaciens (Hirata \& Hayaishi, 1967) and $S$. salivarius (Khandelwal \& Hamilton, 1971) but its $\mathrm{pH}$ optimum (pH 7.5) is lower than that found for $E$. coli ( $\mathrm{pH} 9$ to 10) or B. liquefaciens (Tao \& Lipmann, 1969; Hirata \& Hayaishi, 1967). The effects of metal ions on the $M$. smegmatis enzyme (Table 1) resemble those for the $E$. coli enzyme (Tao \& Lipmann, 1969) although $\mathrm{NH}_{4}{ }^{+}$and $\mathrm{Na}^{+}$were slightly stimulatory in Nocardia erythropolis (Ide, 1971). A greater stimulatory effect of $\mathbf{M n}^{2+}$ compared with $\mathrm{Mg}^{2+}$ was also found in E. coli, B. liquefaciens and Nocardia erythropolis (Ide, 1971). The membrane-bound adenylate cyclase of $N$. crassa specifically required $\mathrm{Mn}^{2+}$ (Flawia \& Torres, 1972). The enzyme from M. smegmatis, like those from $E$. coli (Tao \& Lipmann, 1969), Bordetella pertussis (Hewlett \& Wolff, 1976), S. cerevisiae (Wheeler et al., 1974) and T. pyriformis (Kassis \& Kindler, 1975), was inhibited by fluoride. It resembled other bacterial adenylate cyclases in its unresponsiveness to hormones (Flawia \& Torres, 1972; Wheeler et al., 1974; Hewlett \& Wolff, 1976). Pyruvate inhibited adenylate cyclase activity in $M$. smegmatis, as in $E$. coli (Tao \& Lipmann, 1969) but not B. liquefaciens (Takai et al., 1974; Lynch et al., 1975). NADP+ inhibited much more severely than NADPH. It is possible that metabolic intermediates and related compounds are important in controlling the rate of cyclic AMP formation in this bacterium. The inhibition found with pyrophosphate, one of the products of the adenylate cyclase reaction, resembled that reported for the adenylate cyclase of $S$. cerevisiae (Wheeler et al., 1974), Bordetella pertussis (Hewlett \& Wolff, 1976) and some mammalian tissues (Birnbaumer et al., 1971; Wolff \& Jones, 1971).

I thank Professor J. G. T. Sneyd of the Department of Clinical Biochemistry, University of Otago, Medical School, Dunedin, New Zealand, for his helpful advice during the course of this work. 


\section{REFERENCES}

Birnbaumer, L., Pohl, S. L. \& Rodbell, M. (1971). The glucagon-sensitive adenyl cyclase system in plasma membranes of rat liver. Journal of Biological Chemistry 246, 1857-1860.

ClARK, D. G. S. (1971). Intermediary metabolism in Mycobacterium smegmatis. Ph.D. thesis, University of Otago, New Zealand.

Flawia, M. M. \& Torres, H. N. (1972). Activation of membrane-bound adenylate cyclase by glucagon in Neurospora crassa. Proceedings of the National Academy of Sciences of the United States of America 69, 2870-2873.

GILMAN, A. G. (1970). A protein binding assay for adenosine $3^{\prime}: 5^{\prime}$-cyclic monophosphate. Proceedings of the National Academy of Sciences of the United States of America 67, 305-312.

HeWLetT, E. \& WolfF, J. (1976). Soluble adenylate cyclase from the culture medium of Bordetella pertussis: purification and characterization.Journal of Bacteriology 127, 890-898.

Hirata, M. \& Hayaishi, O. (1967). Adenyl cyclase of Brevibacterium liquefaciens. Biochimica et biophysica acta 149, 1-11.

IDE, M. (1969). Adenyl cyclase of Escherichia coli. Biochemical and Biophysical Research Communications 36, 42-46.

IDE, M. (1971). Adenyl cyclase of bacteria. Archives of Biochemistry and Biophysics 144, 262-268.

KASSIS, S. \& KINDLER, S. H. (1975). Dispersion of epinephrine sensitive and insensitive adenylate cyclase from the ciliate Tetrahymena pyriformis. Biochimica et biophysica acta 391, 513-516.

Khandelwal, R. I. \& Hamilton, I. R. (1971). Purification and properties of adenyl cyclase from Streptococcus salivarius. Journal of Biological Chemistry 246, 3297-3304.
LEE, C. H. (1977). Identification of adenosine $3^{\prime}: 5^{\prime}$ monophosphate in Mycobacterium smegmatis. Journal of Bacteriology 132, 1031-1033.

LEE, C. H. (1978). 3': $5^{\prime}$-Cyclic nucleotide phosphodiesterase of Mycobacterium smegmatis. Journal of General Microbiology 107, 177-181.

Lowry, O. H., Rosebrough, N. J., FARr, A. L. \& Randall, R. J. (1951). Protein measurement with the Folin phenol reagent. Journal of Biological Chemistry 193, 265-275.

LYnch, T. J., Tallant, E. A. \& Cheung, W. Y. (1975). Brevibacterium liquefaciens adenylate cyclase and its in vivo stimulation by pyruvate. Journal of Bacteriology 124, 1106-1112.

Takai, K., Kurashina, Y., SUzUKi-Hori, C., Okamoto, H. \& HaYaishi, O. (1974). Adenylate cyclase from Brevibacterium liquefaciens. I. Purification, crystallization and some properties. Journal of Biological Chemistry 249, 1965-1972.

TAO, M. \& Huberman, A. (1970). Some properties of Escherichia coli adenyl cyclase. Archives of Biochemistry and Biophysics 141, 236-240.

TAO, M. \& LIPMANN, F. (1969). Isolation of adenyl cyclase from Escherichia coli. Proceedings of the National Academy of Sciences of the United States of America 63, 86-92.

Wheeler, G. E., ANGelo, S., Epand, R. M., RatTRAY, J. B. \& KIDBY, D. K. (1974). Subcellular localization and some properties of the adenylate cyclase activity of the yeast Saccharomyces cerevisiae. Biochimica et biophysica acta 372, 15-22.

WolfF, J. \& JoNES, A. B. (1971). The purification of bovine thyroid plasma membranes and the properties of membrane-bound adenyl cyclase. Journal of Biological Chemistry 246, 3939-3947. 